\title{
Association of single nucleotide polymorphisms in the oxidised LDL receptor $1(O L R 1)$ gene in patients with acute myocardial infarction
}

\author{
R Mango, F Clementi, P Borgiani, G B Forleo, M Federici, G Contino, E Giardina, L Garza, I E Fahdi, \\ R Lauro, J L Mehta, G Novelli, F Romeo
}

A cute myocardial infarction (AMI) is a significant cause of mortality and morbidity. Substantial data support a plausible role for oxidised LDL (oxLDL) in the aetiology of this disease. ${ }^{12}$ The human OLRl (or LOX 1) gene encodes the endothelium derived lectin-like oxidised low density lipoprotein (oxLDL) receptor, which is involved in the binding, internalisation, and proteolytic degradation of oxLDL, suggesting that it may play a significant role in atherogenesis." OLRl is considered a good candidate for atherosclerosis and AMI since it is induced in vitro by inflammatory cytokines and in vivo by pro-atherogenic conditions like hypertension, hyperlipidaemia, and diabetes mellitus. ${ }^{4}$ Recently, upregulation of OLRI has been shown in ischaemia reperfusion injury in the rat. ${ }^{5}$ OLRl acts as a mediator of "endothelial dysfunction" favouring superoxide generation, inhibiting nitric oxide production, and enhancing endothelial adhesiveness for monocytes. ${ }^{6-8}$ It is noteworthy that the versatile activities of OLRI also include the ability to bind not only oxLDL, but also aged red blood cells, apoptotic cells, and activated platelets. ${ }^{4}$ With this background, we sought to validate the hypothesis of OLRl involvement in atherosclerosis and AMI by defining OLRl genetic variation by an association study of intragenic SNPs.

\section{METHODS}

\section{Study subjects}

The study included 150 individuals with AMI who were referred to the Centre of Atherosclerosis at the Medical School of the Tor Vergata University of Rome. All cases were clinically evaluated and all underwent coronary angiography and left ventriculography. The diagnosis of AMI was based on typical electrocardiographic changes and increased serum activities of at least two enzymes, such as creatine kinase, aspartate aminotransferase, and lactate dehydrogenase. The diagnosis was confirmed by the presence of wall motion abnormality on left ventriculography and attendant stenosis $(>50 \%)$ in any of the major coronary arteries or in the left main coronary artery on coronary angiography. One hundred and three control subjects were recruited from persons found to have at least one conventional risk factor for coronary artery disease (CAD), such as cigarette smoking ( 10 cigarettes daily), hypertension (systolic blood pressure of $140 \mathrm{~mm} \mathrm{Hg}$ or diastolic blood pressure $90 \mathrm{~mm} \mathrm{Hg}$ ), diabetes mellitus (blood glucose level $126 \mathrm{mg}$ per decilitre (6.93 mmol per litre)), hypercholesterolaemia (total serum cholesterol level $220 \mathrm{mg}$ per decilitre $(5.72 \mathrm{mmol}$ per litre) $)$. These subjects had no evidence of active myocardial ischaemia, but underwent left ventriculography and coronary angiography as part of valvular disease. All these control subjects were found to have normal coronary arteries. The mean age of the AMI patients was 64.4 ( 5.8 years) (mean (SD)) with a mean age at onset of symptoms 60.4 (4.5) years. The mean age of the

\section{Key points}

- OLR1 is a cell surface endocytosis receptor for atherogenic oxidised LDL (oxLDL), which is strongly expressed in endothelial cells. Recent studies suggest that it may be involved in the development of atherosclerosis and its complications.

- We genotyped 253 individuals for OLR1 gene polymorphisms: 150 individuals with acute myocardial infarction (AMI) and 103 healthy controls.

- We identified six novel single nucleotide polymorphisms (SNPs) within intron 4, intron 5, and the 3'UTR. The six polymorphisms were in complete linkage disequilibrium.

- Carriers of the T allele (CT/TT) at the SNP located in the $3^{\prime}$ UTR (C>T, 188 bp from the stop codon) exhibited a significant association with $\mathrm{AMI}(\mathrm{p}<0.0001)$ with an odds ratio (OR) of 3.74 .

control subjects was $63.4(6.2)$ years. The study was approved by the Tor Vergata University Ethics Committee.

\section{SNP discovery and genotyping}

All six exons and intron/exon boundaries of OLRl were screened using denaturing high performance liquid chromatography (DHPLC, Transgenomic, Crewe, UK) in 50 AMI patients and 50 controls according to the conditions reported in table 1 . Identified SNPs were characterised by sequencing on a CEQ2000 automated sequencer (Beckman Coulter Inc., USA). All samples were genotyped for the OLRI/3'UTR and the K167N polymorphisms by allelic discrimination assays. We designed primers and MGB probes (OLRI/ 3'UTR forward primer: 5'GCCTGGCACCTTTATGTCAAC-3'; OLRI/3'UTR reverse primer:

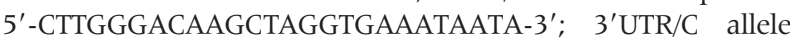
MGB probe : 5'-FAM-TTTTTGATTCTAGCTACCTG-3'; $3^{\prime}$ UTR/T allele MGB probe: 5'-VIC-ATTTTTGATTCTAGCTATCTG-3'; K167N forward primer: 5'-GCAACTTGGCATCCAAÄGACA3'; K167N reverse primer: 5'-CCTATTTTCCTCGGGCTCATT3'; K167N/G allele 5'-FAM-TTCTCTTGGCTCTTTT-3'; K167N/ C allele $5^{\prime}$-VIC-CTTCTCTTGGCTGTTTT- $\left.{ }^{\prime}{ }^{\top}\right)$ using Primer Express 2.0 software (Applied Biosystems, Foster City, CA). PCR amplification was carried out in a reaction

Abbreviations: $A M l$, acute myocardial infarction; $C A D$, coronary artery disease; OLR1, oxidised LDL receptor 1; OR, odds ratio; oxLDL, oxidised LDL; SNP, single nucleotide polymorphism; TNF, tumour necrosis factor 


\begin{tabular}{|c|c|c|c|c|}
\hline OLRI & $\begin{array}{l}\text { Fragment } \\
\text { (bp) }\end{array}$ & Primers $\left(5^{\prime}-3^{\prime}\right)$ & PCR conditions & DHPLC conditions \\
\hline Exon 1 & 238 & $\begin{array}{l}\text { F: acttctgcagaagctcac } \\
\text { R: ctaatcccattcttcggtg }\end{array}$ & $\begin{array}{l}94^{\circ} \mathrm{C} 15 \mathrm{~s}, 54^{\circ} \mathrm{C} 30 \mathrm{~s}, 72^{\circ} \mathrm{C} 30 \mathrm{~s} \\
\text { over } 35 \text { cycles }\end{array}$ & $57^{\circ} \mathrm{C}$ \\
\hline Exon 2 & 230 & 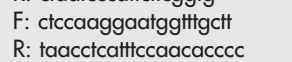 & $\begin{array}{l}94^{\circ} \mathrm{C} 15 \mathrm{~s}, 60^{\circ} \mathrm{C} 30 \mathrm{~s}, 72^{\circ} \mathrm{C} 30 \mathrm{~s} \\
\text { over } 35 \text { cycles }\end{array}$ & $59^{\circ} \mathrm{C}$ \\
\hline Exon 3 & 355 & $\begin{array}{l}\text { F: cctggagggattlttattlgg } \\
\text { R: tgattggacagaaagcttcca }\end{array}$ & $\begin{array}{l}94^{\circ} \mathrm{C} 15 \mathrm{~s}, 60^{\circ} \mathrm{C} 30 \mathrm{~s}, 72^{\circ} \mathrm{C} 30 \mathrm{~s} \\
\text { over } 35 \text { cycles }\end{array}$ & $59^{\circ} \mathrm{C}$ \\
\hline Exon 4 & 333 & $\begin{array}{l}\text { F: atgcacgtgagagactaaggg } \\
\text { R: tggctctcaaacaagaattcc }\end{array}$ & $\begin{array}{l}94^{\circ} \mathrm{C} 15 \mathrm{~s}, 62^{\circ} \mathrm{C} 30 \mathrm{~s}, 72^{\circ} \mathrm{C} 30 \mathrm{~s} \\
\text { over } 35 \text { cycles }\end{array}$ & $58^{\circ} \mathrm{C}$ \\
\hline Exon 5 & 263 & $\begin{array}{l}\text { F: cagtcaaggggatgtcaaaga } \\
\text { R: gaggcatcaaaaagaatggg }\end{array}$ & $\begin{array}{l}94^{\circ} \mathrm{C} 15 \mathrm{~s}, 60^{\circ} \mathrm{C} 30 \mathrm{~s}, 72^{\circ} \mathrm{C} 30 \mathrm{~s} \\
\text { over } 35 \text { cycles }\end{array}$ & $59^{\circ} \mathrm{C}$ \\
\hline Exon 6 & 400 & $\begin{array}{l}\text { F: tgaaggctctggaagaaaagg } \\
\text { R: tgtgaggggaaggtgataatg }\end{array}$ & $\begin{array}{l}94^{\circ} \mathrm{C} 15 \mathrm{~s}, 59^{\circ} \mathrm{C} 30 \mathrm{~s}, 72^{\circ} \mathrm{C} 30 \mathrm{~s} \\
\text { over } 35 \text { cycles }\end{array}$ & $58^{\circ} \mathrm{C}$ \\
\hline 3'UTR & 403 & 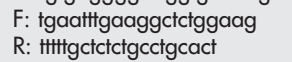 & $\begin{array}{l}94^{\circ} \mathrm{C} 15 \mathrm{~s}, 60^{\circ} \mathrm{C} 30 \mathrm{~s}, 72^{\circ} \mathrm{C} 30 \mathrm{~s} \\
\text { over } 35 \text { cycles }\end{array}$ & $58^{\circ} \mathrm{C}$ \\
\hline
\end{tabular}

volume of $25 \mu \mathrm{l}$ containing $900 \mathrm{nM}$ of each primer, $200 \mathrm{nM}$ of each probe, $12.5 \mu \mathrm{l}$ of TaqMan universal Master Mix (Applied Biosystems) and 50 ng of genomic DNA. PCR was performed on an ABI prism 7000 sequence detection system (Applied Biosystems) using the following conditions: after enzyme activation for $10 \mathrm{~min}$ at $95^{\circ} \mathrm{C}, 40$ two step cycles were performed; $15 \mathrm{~s}$ denaturation at $95^{\circ} \mathrm{C}$ followed by $1 \mathrm{~min}$ annealing/elongation at $60^{\circ} \mathrm{C}$ for both OLRl/ $3^{\prime}$ UTR and K167N polymorphisms. The allelic specific fluorescence was measured on the ABI prism 7000 sequence detection system using the ABI Prism 7000 SDS software. The genotype calls were attributed automatically.

\section{Statistical analysis}

Differences in genotype and allele proportion between patients and controls and differences between observed and expected genotype frequencies (assuming Hardy-Weinberg equilibrium) were evaluated by Pearson's $\chi^{2}$ test of independence. Linear association was assessed using the MantelHaenszel test. Analysis of risk factors was also conducted using the $\chi^{2}$ test and discriminant analysis. All these statistical analyses (and the OR determination) were performed using SPSS ( Statistical package for social sciences, SPSS Inc., Chicago, IL). Haplotype frequencies were maximum-likelihood estimates (MENDEL software, Department of Biostatistics, University of Michigan, Ann Arbor, MI). The disequilibrium coefficient (D) was calculated as:

(product of coupling types) $\div$ (product of repulsion types).

\section{RESULTS}

To identify SNPs in the OLRI gene, we screened all exons and intron/exon boundaries in 50 patients and 50 controls using DHPLC. The samples that showed an anomalous elution profile were sequenced to characterise the allelic variants. We identified seven SNPs in the OLRl gene using this method. These SNPs were then genotyped in the sample using allelic discrimination assays. Allele and genotype frequencies of the seven studied polymorphisms are reported in table 2 for AMI patients and control subjects. All genotype distributions were compatible with Hardy-Weinberg equilibrium. Among the seven polymorphisms, six of them (located within introns 4, 5 and 3'UTR) comprised a complete linkage disequilibrium block behaving as a single SNP. This suggests the existence of a linkage disequilibrium block which includes at least intron 4, exon 5, intron 5 and 3'UTR. The OLRI/3'UTR polymorphism $(\mathrm{C}>\mathrm{T}, 188 \mathrm{bp}$ from the stop codon) showed the most significant association when AMI patients and controls were compared $(\mathrm{p}<0.0001)$ (table 2$)$. Genotypes with the T allele (CT or TT) at this SNP were found in $91.3 \%$ of the patients compared with $73.8 \%$ of the controls, $(p=0.0003)$ which resulted in an odds ratio (OR) of 3.74 (95\% confidence limits: 1.73 and 8.18 ). The SNP located in exon 4 , which produces a conservative amino acid change $(K>N$ at codon 167) demonstrated a weak association. We also performed haplotype analysis considering the OLRI/3'UTR and the K167N polymorphisms but the association found with AMI was not higher than that observed considering OLRI/3'UTR

Table 2 Description of studied OLRI SNPs and distribution of their genotypic and allelic frequencies in controls and AMI patients*

\begin{tabular}{|c|c|c|c|c|c|c|c|c|c|c|c|c|c|c|c|}
\hline \multirow[b]{2}{*}{ Location } & \multirow[b]{2}{*}{ Substitution } & & \multicolumn{3}{|c|}{ Genotypic frequencies } & \multirow[t]{2}{*}{$\begin{array}{l}\text { Total } \\
\text { no }\end{array}$} & \multirow[t]{2}{*}{$\chi^{2}$} & \multirow[t]{2}{*}{$\mathrm{df}$} & \multirow[t]{2}{*}{$\mathbf{p}$} & \multirow[t]{2}{*}{$\mathbf{p}^{\wedge}$} & \multicolumn{2}{|c|}{$\begin{array}{l}\text { Allelic } \\
\text { frequencies }\end{array}$} & \multirow[t]{2}{*}{$\chi^{2}$} & \multirow[t]{2}{*}{ df } & \multirow[t]{2}{*}{$\mathbf{p}$} \\
\hline & & & GG & $G C$ & $C C$ & & & & & & $G$ & C & & & \\
\hline \multirow[t]{2}{*}{ Exon 4} & $\mathrm{~K} 167 \mathrm{~N}(501 \mathrm{G}>\mathrm{C})$ & $\begin{array}{l}\text { Controls } \\
\text { Patients }\end{array}$ & $\begin{array}{l}0.825 \\
0.913\end{array}$ & $\begin{array}{l}0.165 \\
0,087\end{array}$ & $\begin{array}{l}0.010 \\
0,000\end{array}$ & $\begin{array}{l}103 \\
150\end{array}$ & 5.16 & 2 & 0.07 & 0.03 & $\begin{array}{l}0.908 \\
0.957\end{array}$ & $\begin{array}{l}0.092 \\
0.043\end{array}$ & 4.139 & 1 & 0.04 \\
\hline & & & CC & $C T$ & $\pi$ & & & & & & C & 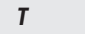 & & & \\
\hline $3^{\prime}$ UTR & ${ }^{*} 188 \mathrm{C}>\mathrm{T}$ & $\begin{array}{l}\text { Controls } \\
\text { Patients }\end{array}$ & $\begin{array}{l}0.262 \\
0.087\end{array}$ & $\begin{array}{l}0.573 \\
0.546\end{array}$ & $\begin{array}{l}0.165 \\
0.367\end{array}$ & $\begin{array}{l}103 \\
150\end{array}$ & 20.69 & 2 & $<0.0001$ & 0 & $\begin{array}{l}0.548 \\
0.360\end{array}$ & $\begin{array}{l}0.452 \\
0.640\end{array}$ & 16.89 & 1 & 0.0004 \\
\hline $\begin{array}{l}\text { Intron } 4 \\
\text { Intron } 4 \\
\text { Intron } 4 \\
\text { Intron } 5 \\
\text { Intron } 5\end{array}$ & $\begin{array}{l}\text { IVS4+27 G>C } \\
\text { IVS4-73 C>T } \\
\text { IVS4-14 A>G } \\
\text { IVS5-70 A>G } \\
\text { IVS5-27 G>T }\end{array}$ & \multicolumn{14}{|c|}{ genotypic and allelic frequencies are identical to the $3^{\prime} \cup T R{ }^{*} 188 \mathrm{C}>\mathrm{T}$} \\
\hline
\end{tabular}




\begin{tabular}{|c|c|c|c|c|c|c|}
\hline Risk factor & & Controls & Patients & $\mathbf{p}$ & $\begin{array}{l}\text { Comparison } \\
\text { with K167N }\end{array}$ & $\begin{array}{l}\text { Comparison } \\
\text { with *188 C>T }\end{array}$ \\
\hline Hypertension & $\begin{array}{l}\text { Absent } \\
\text { Present }\end{array}$ & $\begin{array}{l}41.4 \% \\
58.6 \%\end{array}$ & $\begin{array}{l}40.7 \% \\
59.3 \%\end{array}$ & ns & ns & ns \\
\hline Diabetes & $\begin{array}{l}\text { Absent } \\
\text { Present }\end{array}$ & $\begin{array}{l}94.3 \% \\
5.7 \%\end{array}$ & $\begin{array}{l}75.9 \% \\
24.1 \%\end{array}$ & 0.001 & ns & ns \\
\hline Hyperlipidaemia & $\begin{array}{l}\text { Absent } \\
\text { Present }\end{array}$ & $\begin{array}{l}65.7 \% \\
34.3 \%\end{array}$ & $\begin{array}{l}38.4 \% \\
61.6 \%\end{array}$ & 0 & ns & ns \\
\hline Cigarefte smoking & $\begin{array}{l}\text { Absent } \\
\text { Present }\end{array}$ & $\begin{array}{l}64.3 \% \\
35.7 \%\end{array}$ & $\begin{array}{l}28.3 \% \\
71.7 \%\end{array}$ & 0 & ns & ns \\
\hline Familiarity & $\begin{array}{l}\text { Absent } \\
\text { Present }\end{array}$ & $\begin{array}{l}82.9 \% \\
17.1 \%\end{array}$ & $\begin{array}{l}62.4 \% \\
37.6 \%\end{array}$ & 0.002 & ns & ns \\
\hline Sex & $\begin{array}{l}\text { Male } \\
\text { Female }\end{array}$ & $\begin{array}{l}56 \% \\
44 \%\end{array}$ & $\begin{array}{l}72 \% \\
28 \%\end{array}$ & 0.01 & ns & ns \\
\hline
\end{tabular}

polymorphism alone. Since this analysis does not add further information to the association, these data are not included. To explore the interaction of OLRI SNPs on different risk factors, we performed the $\chi^{2}$ test which revealed a complete independence of each single risk factor (table 3 ) from SNPs detected. When all risk factors (K167N, OLRl/3'UTR polymorphism and CAD risk factors) were considered by discriminant analysis (direct method), a significant separation between patients and controls subjects was observed $(p<0.0001)$. The two variables that mainly contributed to the discrimination of the two groups were cigarette smoking and OLRl/3'UTR polymorphism with a correlation of 0.54 and 0.47 , respectively. Significance of contribution of a variable to separation of the two groups was also evaluated by the change in Rao's V produced by entering the variable into the discriminant function. The results confirmed that cigarette smoking and OLRI/3'UTR polymorphism showed the highest significance levels.

\section{DISCUSSION}

The identification of susceptibility genes is of major biomedical interest. Genetic association studies and linkage analysis have identified several genetic loci involved in atherosclerosis and its major life threatening complication, the acute coronary syndrome. ${ }^{9-11}$ The present study provides support for a significant novel genetic component to the development of AMI. There is accumulating evidence that acute coronary syndromes relate to the activation of chronic inflammation in the stable atherosclerotic plaque resulting in abrupt rupture. The vulnerable plaque has been shown to contain large amounts of oxLDL, over expression of its newly described lectin-like receptor OLRl, and a large number of monocytes/macrophages. Recent studies suggest that OLRI expression is also upregulated in the myocardium in acute myocardial ischaemia. ${ }^{5}$ OLRl specifically interacts with oxLDL, but not the native LDL, suggesting that OLRl expression may be involved in atherogenesis. The expression of OLRl is upregulated by various pro-atherosclerotic stimulants, including angiotensin II, TNF- $\alpha$, PMA, and lysophosphatidytilcholine. ${ }^{12}$ These observations suggest that OLRl may be expressed locally and play important roles in inflammatory responses in vivo and rupture of the atherosclerotic plaque resulting in acute coronary syndrome. ${ }^{13}$ Further evidence that OLRl is directly involved in the atherogenesis comes from inbred strains of LDLr $-/-$ mice and Olrl knockout mice (JL Mehta et al, unpublished data) in which the development of atherosclerosis is attenuated. Interestingly, Welch et al $^{9}$ identified and mapped a susceptibility to atherosclerosis locus in mice (Athsq2) in a syntenic region with the human chromosome 12pl3-12, which contains the OLRl gene. The present study was designed to verify whether OLRI SNPs influence the AMI susceptibility in the Italian population. We observed that the OLRI/3'UTR SNP genotype and allele frequencies were differed significantly between the control and the AMI groups. Our data showed that subjects with the T/T or C/T genotype at OLRl/ 3'UTR polymorphism are at higher risk of developing acute AMI (OR, 3.74). The Kl67N polymorphism, despite its weak association, causes an amino acid substitution at codon 167 (Lys $>$ Asn) which is located within the C-type lectin domain of the protein. Replacement of this Lys residue causes reduced binding and internalisation of oxLDL. ${ }^{14}$ Therefore, we can speculate that this SNP could exert a protective effect. However, recently, Tatsuguchi et $\mathrm{al}^{15}$, has reported a positive association of the $\mathrm{K} 167 \mathrm{~N}$ polymorphism with the risk of myocardial infarction in a sample of Japanese patients. This discrepancy may be attributed to a different genetic background in the population studied, or to the different selection of the patients and healthy controls. During the preparation of the present manuscript, Chen et $\mathrm{al}^{16}$ reported the association of three OLRI SNPs with the risk of CAD in white women. The three OLRl polymorphisms studied by these authors correspond to our SNPs. These authors reported an odds ratio of $1.67(\mathrm{p}=0.025)$ and an absence of interaction between the OLRl and APOE genes. Notably, they observed that the OLRl/3'UTR polymorphism may affect the binding of a putative transcription factor, as deduced by the electrophoretic mobility shift assay. This study further supports the function of OLRl as a risk related gene for heart disease.

Many studies have examined the relations between polymorphisms and coronary artery disease or myocardial infarction. The results of most of these studies, however, remain controversial, with no consensus in their implications, mainly because of the limited size of the study populations, the ethnic diversity of polymorphisms, and complicating environmental factors. In this context, OLRl seems to have all the features required (large sample sizes, small $p$ values, SNPs with putative biological effects, independent replication of studies) to be of clinical relevance. The association reported in the present study confirms the previously reported association of the OLRI/3'UTR SNP and so it provides credence to the hypothesis that the OLRI gene product is involved in the pathogenesis of AMI.

\footnotetext{
Authors' affiliations

R Mango, F Clementi, P Borgiani, G B Forleo, M Federici, G Contino, E Giardina, R Lauro, G Novelli, F Romeo, Centre of Excellence for Genomic Risk Assessment in Multifactorial and Complex Diseases, School of Medicine, Tor Vergata University of Rome, Italy
} 
L Garza, I E Fahdi, J L Mehta, Department of Internal Medicine, University of Arkansas for Medical Sciences, Little Rock, USA

This work was supported by grants from the Italian Ministry of Education, University and Research (Fondi Centri di Eccellenza 2000 and COFIN 2002).

Correspondence to: Giuseppe Novelli, Dipartimento di Biopatologia e Diagnostica per Immagini, Università di Roma "Tor Vergata", Via

Montpellier 100133 Roma, Italy; novelli@med.uniroma2.it

\section{REFERENCES}

1 Ehara S, Ueda M, Naruko T, et al. Pathophysiological role of oxidized lowdensity lipoprotein in plaque instability in coronary artery diseases. J Diabetes Complications 2002;16:60-4.

2 Kelishadi R, Nadery GA, Asgary S. Oxidized LDL metabolites with high family risk for premature cardiovascular disease. Indian J Pediatr 2002:69:7557-9.

3 Sawamura T, Kume N, Aoyama T, et al. An endothelial receptor for oxidized low-density lipoprotein. Nature 1997;886:73-7.

4 Mehta JL, Li DY. Identification, regulation and function of LOX-1, a novel receptor for ox-LDL. J Am Coll Cardiol 2002;39:1429-35.

5 Li D, Williams V, Liu L, et al. LOX-1 inhibition in myocardial ischemiareperfusion injury: modulation of MMP-1 and inflammation. Am J Physio Heart Circ Physiol 2002;283:H1795-801.

6 Li DY, Mehta JL. Antisense to LOX-1 inhibits ox-LDL-mediated upregulation of MCP-1 expression and monocyte adhesion to human coronary artery endothelial cells. Circulation 2000;101:2889-95.
7 Cominacini L, Pasini AF, Garbin U, et al. Oxidized low-density lipoprotein (ox-LDL) binding to ox-LDL receptor-1 in endothelial cells induces the activation of NF-kB through an increased production of intracellular reactive oxygen species. J Biol Chem 2000;275:12633-8.

8 Mehta JL, Li DY, Chen HJl, et al. Inhibition of LOX-1 by statins may relate to upregulation of eNOS. Biochem Biophys Res Commun 2001;289:857-61.

9 Welch CL, Bretschger S, Latib N, et al. Localization of atherosclerosis susceptibility loci to chromosomes 4 and 6 using the Ldlr Knockout mouse model. Proc Natl Acad Sci U S A 2001;98:7946-51.

10 Broeckel U, Hengstenberg C, Mayer B, et al. A comprehensive linkage analysis for myocardial infarction and its related risk factors. Nat Genet 2002;30:210-4.

11 Ozaki K, Ohnishi Y, lida A, et al. Functional SNPs in the lymphotoxin-alpha gene that are associated with susceptibility to myocardial infarction. Nat Genet 2002:32:650-4

12 Shi X, Niimi S, Ohtani T, et al. Characterization of residues and sequences of the carbohydrate recognition domain required for cell surface localization and ligand binding of human lectin-like oxidized IDL receptor. J Cell Sci 2001;114:1273-82.

13 Li DY, Chen HJ, Staples ED, et al. Oxidized LDL receptor LOX-1 and apoptosis in human atherosclerotic lesions. J Cardiovasc Pharmacol Ther 2002;7: 147-53.

14 Chen M, Narumiya S, Masaki T, et al. Conserved C-terminal residues within the lectin-like domain of LOX-1 are essential for oxidized low-densitylipoprotein binding. Biochem J 2001;355:289-96.

15 Tatsuguchi $M$, Furutani $M$, Hinagata J, et al. Oxidized LDL receptor gene (OLR 1) is associated with the risk of myocardial infarction. Biochem Biophys Res Commun 2003;28:247-50.

16 Chen QI, Reis SE, Kammerer c, et al. Genetic variation in lectin-like oxidized low-density lipoprotein receptor 1 (LOX1) gene and the risk of coronary artery disease. Circulation 2003;107:3146-51.

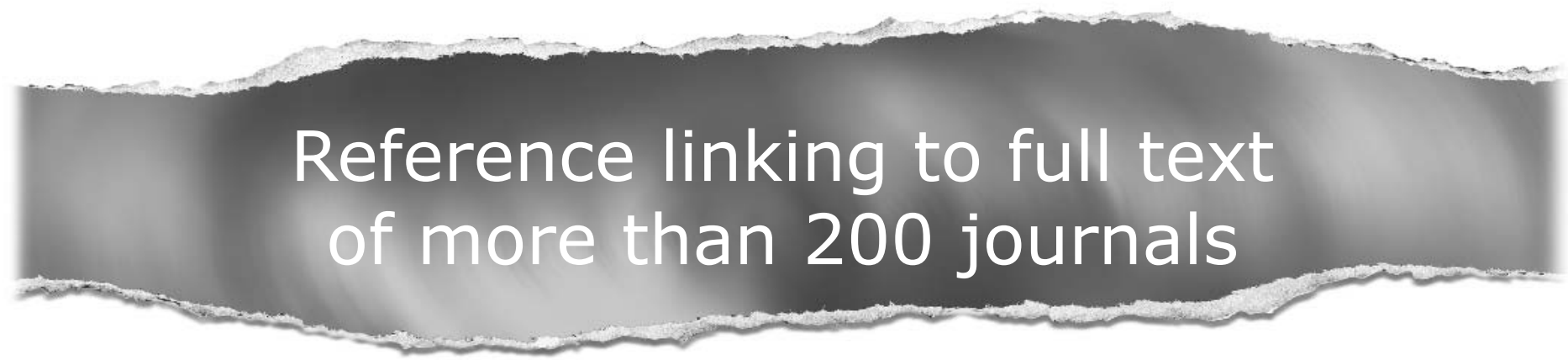

Toll free links

You can access the FULL TEXT of articles cited in the Journal of Medical Genetics online if the citation is to one of the more than 200 journals hosted by HighWire (http://highwire.stanford.edu) without a subscription to that journal. There are also direct links from references to the Medline abstract for other titles.

\section{www.jmedgenet.com}

